\title{
Hubungan Riwayat Keluarga, Berat Bayi Lahir, Usia Gestasi, dan Riwayat Konsumsi Susu Formula dengan Penyakit Refluks Gastroesofagus pada Bayi Usia 3 Minggu - 12 Bulan
}

Puthisari Zonya Jannata, ${ }^{1}$ Yusri Dianne Jurnalis, ${ }^{1}$ Muhammad Hidayat ${ }^{2}$

${ }^{1}$ Bagian Ilmu Kesehatan Anak, ${ }^{2}$ Bagian Ilmu Kesehatan Mata Fakultas Kedokteran Universitas Andalas/RSUP Dr. M. Djamil, Padang

Latar belakang. Penyakit Refluks Gastroesofagus (PRGE) merupakan kondisi isi lambung kembali ke esofagus atau orofaring kemudian menimbulkan gejala dan/atau komplikasi pada bayi. Patofisiologi PRGE tidak terlepas dari adanya berbagai faktor risiko pada bayi, seperti riwayat keluarga dengan PRGE, berat bayi lahir, usia gestasi, dan riwayat konsumsi susu formula.

Tujuan. Mengetahui hubungan riwayat keluarga PRGE, berat bayi lahir, usia gestasi, dan riwayat konsumsi susu formula dengan PRGE pada bayi usia 3 minggu - 12 bulan di Puskesmas Andalas.

Metode. Studi potong lintang dilakukan pada Februari-Maret 2021 terhadap 82 bayi usia 3 minggu - 12bulan di Puskesmas Andalas, Padang. Data didapatkan dengan wawancara orang tua bayi menggunakan kuesioner PRGE IDAI dan kuesioner GERD-Q yang sebelumnya sudah menandatangi lembar persetujuan orang tua.

Hasil. Bayi usia 3 minggu-6 bulan dan berjenis kelamin laki-laki paling banyak didapat PRGE. Hasil uji chi-square didapatkan riwayat keluarga PRGE ( $\mathrm{p}=0,455)$, berat bayi lahir $(\mathrm{p}=0,029)$, usia gestasi $(\mathrm{p}=0,022)$, dan riwayat konsumsi susu formula $(\mathrm{p}=0,033)$ Hasil analisis regresi logistik didapatkan riwayat konsumsi susu formula menjadi faktor paling dominan dengan kejadian PRGE pada bayi dengan OR=3,210.

Kesimpulan. Terdapat hubungan yang bermakna antara berat bayi lahir, usia gestasi, dan riwayat konsumsi susu formula dengan kejadian PRGE pada bayi. Sari Pediatrỉ 2021;23(3):178-84

Kata kunci: bayi, berat bayi lahir, PRGE, riwayat keluarga PRGE, susu formula, usia gestasi

\section{Correlation between Family History, Birth Weight, Gestation Age, and Feeding Formula History with Gastroesophageal Reflux Disease in Infants Aged 3 Weeks - 12 Months}

Puthisari Zonya Jannata, ${ }^{1}$ Yusri Dianne Jurnalis, ${ }^{1}$ Muhammad Hidayat ${ }^{2}$

Background. Gastroesophageal Reflux Disease (GERD) occurs when stomach contents back up into the esophagus or oropharynx, which will lead to symptoms and/or complications. GERD's pathophysiology relates to the risk factor, there are family history GERD, birth weight, gestation age, and formula feeding history.

Objective. The study was aim to know the correlation between family history of GERD, birth weight, gestation age, and formula feeding history with GERD in infants aged 3 weeks -12 months in Puskesmas Andalas.

Methods. This cross-sectional study was performed in February - March 2021 on 82 infants aged 3 weeks - 12 months in Puskesmas Andalas, Padang. Data were collected by using I-GERQ and GERD-Q through interviewing parents who had previously been approved by the parents. Result. Most GERD in infants were aged 3 weeks -6 months and male. The results of this study based on chi-square test showed that family history $(\mathrm{p}=0,455)$, birth weight $(\mathrm{p}=0,029)$, gestation age $(\mathrm{p}=0,022)$, and formula feeding history $(\mathrm{p}=0,033)$. The result based on logistic regression test showed that feeding formula history was the most dominant related to GERD in infants with OR=3,219.

Conclusion. There is significant statistical correlation between birth weight, gestation age, and formula feeding history with GERD in infants. While gamily history GERD was not found to be a significant correlation with GERD in the infant. Sari Pediatri 2021;23(3):178-84

Keywords: infants, birth weight, GERD, family history GERD, formula feeding, gestation age

Alamat korespondensi: Yusri Dianne Jurnalis, Departemen Ilmu Kesehatan Anak FK UNAND/RSUP dr. M. Djamil Jl. Perintis Kemerdekaan. Padang, Sumatera Barat. Email : dianneyusri5@gmail.com 
Puthisari Zonya Jannata dkk: Hubungan riwayat keluarga, berat bayi lahir, usia gestasi, dan riwayat konsumsi susu formula dengan PRGE pada bayi usia 3 minggu - 12 bulan

$\mathrm{R}$ efluks gastroesofagus (RGE) merupakan salah satu gangguan saluran cerna fungsional pada bayi berupa proses fisiologis keluarnya isi lambung secara involunteer lalu masuk ke dalam esofagus tanpa terlihat upaya bayi untuk mengeluarkannya. Hal ini berhubungan dengan fungsi motilitas saluran cerna bayi yang belum sepenuhnya berkembang. ${ }^{1,2}$ Regurgitasi merupakan manifestasi utama dari RGE, yaitu dikeluarkannya isi refluks dari esofagus ke dalam mulut lalu dikeluarkan dari rongga mulut yang dapat terjadi minimal satu kali perhari dengan persentase paling tinggi pada usia 1 bulan dan menurun seiring dengan bertambahnya usia. ${ }^{2-4}$ Prevalensi terkait gangguan fungsional gastrointestinal pada bayi usia 3 minggu-12 bulan dilaporkan Steutel, $\mathrm{dkk}^{5}$ di Eropa. Steutel $\mathrm{dkk}^{5}$ menemukan 24,7\%, keluhan terbanyak merupakan regurgitasi , (13,8\%).

Kondisi patologis dari RGE adalah penyakit refluks gastroesofagus (PRGE), yaitu keadaan ketika isi lambung naik kembali ke dalam esofagus atau orofaring dan menimbulkan gejala dan/atau komplikasi. ${ }^{6,7}$ Penelitian di Turki oleh Rala $\mathrm{dkk}^{8}$ ditemukan 14\% bayi mengalami PRGE. Di Jakarta, Hasibuan $\mathrm{dkk}^{9}$ menemukan 58 pasien yang didiagnosis PRGE, 20,7\% di antaranya berumur 0-24 bulan. Penelitian Andini yang dilakukan di Posyandu wilayah kerja Puskesmas Seberang Padang, Kota Padang juga melaporkan 18,1\% bayi usia 1 sampai 12 bulan dicurigai PRGE. ${ }^{10}$ Angka tersebut tidak jauh berbeda dengan hasil preliminary survey yang dilakukan oleh peneliti, yaitu ditemukan kejadian PRGE 19,04\% di Puskesmas Andalas.

Berbagai komplikasi PRGE yang terjadi secara kronis pada bayi, di antaranya adalah gagal tumbuh karena defisit kalori dan barrett's esophagus yang dapat berkembang menjadi kanker esofagus. Keadaan ini tidak jarang ditemukan pada usia dewasa muda dan akan memengaruhi kualitas hidup pada anak. ${ }^{11,12}$

Proses terjadinya PRGE diduga karena adanya berbagai faktor risiko pada bayi, di antaranya adalah riwayat keluarga dengan PRGE, bayi berat lahir rendah, bayi prematur, riwayat konsumsi susu formula, dan kelainan kongenital esofagus. ${ }^{7}$ Selain itu, dugaan pengaruh faktor ibu, seperti volume ASI dan frekuensi menyusui yang berlebihan serta cara menyusui yang kurang tepat. ${ }^{13,14}$

Belum ada data terkait kejadian PRGE pada bayi di Sumatera Barat, khususnya di Kota Padang. Namun, penelitian menunjukkan adanya hubungan antara
BBLR dengan kejadian PRGE pada bayi. ${ }^{13}$ Data profil kesehatan Indonesia tahun 2019 tercatat 3,3\% BBLR di Sumatera Barat dan di Kota Padang. Jumlah BBLR dilaporkan 1,7\%, dan tertinggi di Puskesmas Andalas, yaitu 26 kasus dari 1548 (1,7\%) bayi. ${ }^{16,17}$ Angka tersebut meningkat dari tahun sebelumnya yang dilaporkan 23 kasus dari 1511 (1,52\%) bayi. ${ }^{18}$ Selain itu, data sasaran Puskesmas Andalas tahun 2020 melaporkan terdapat 1531 bayi usia 3 minggu-12 bulan, jika dibandingkan dengan jumlah bayi tahun sebelumnya, maka dapat diprediksi angka BBLR kemungkinan akan meningkat pula. Maka dari itu, angka kejadian PRGE pun dapat diprediksi akan meningkat dikarenakan BBLR merupakan salah satu faktor risiko yang berperan pada PRGE.

Oleh karena itu, penelitian ini dilakukan untuk mengetahui hubungan riwayat keluarga PRGE, berat bayi lahir, usia gestasi, dan riwayat konsumsi susu formula dengan PRGE pada bayi usia 3 minggu - 12 bulan di Puskesmas Andalas

\section{Metode}

Penelitian dilaksanakan pada bayi di Puskesmas Andalas, Padang. Jenis penelitian ini adalah analitik dengan rancangan cross sectional. Variabel independen adalah PRGE dan variabel dependen adalah riwayat keluarga PRGE, berat bayi lahir, usia gestasi, dan riwayat konsumsi susu formula. Penelitian dilakukan pada bulan Februari-Maret 2021.

Populasi adalah bayi berusia 3 minggu - 12 bulan di Puskesmas Andalas yang mengalami PRGE dan tidak PRGE. Sampel penelitian dilakukan dengan teknik konsekutif yang didapatkan 82 bayi dengan 41 bayi dengan PRGE dan 41 bayi dengan tidak PRGE yang memenuhi kriteria inklusi dan eksklusi. Kriteria inklusi adalah orang tua bayi yang bersedia mengikuti penelitian dengan menandatangani informed consent dan bayi berusia 3 minggu-12 bulan yang berdomisili dan/ atau tinggal di wilayah kerja Puskesmas Andalas. Kriteria eksklusi adalah bayi yang pernah mengalami kelainan kongenital pada esofagus dan orang tua bayi yang tidak membawa buku KIA/buku KIA tidak lengkap.

Pengumpulan data digunakan kuesioner PRGE rekomendasi Ikatan Dokter Anak Indonesia (IDAI) dan kuesioner GERD rekomendasi Perkumpulan Gastroenterologi Indonesia (PGI). Responden yang 
memenuhi kriteria inklusi menandatangani lembar persetujuan untuk bersedia mengikuti penelitian terlebih dahulu. Selanjutnya, ditanyakan terkait data bayi, seperti nama, tempat tanggal lahir, usia, jenis kelamin, berat bayi lahir, usia gestasi, riwayat konsumsi susu formula, dan riwayat kelainan kongenital esofagus serta data ibu dan data ayah. Kemudian, orang tua diwawancarai sesuai pertanyaan yang tertera di kuesioner.

Data yang diambil tersebut dimasukkan ke dalam program SPSS untuk dianalisis. Analisis bivariat menggunakan uji statistika chi-square. Jika nilai $\mathrm{p}<0,05$, maka terdapat hubungan yang bermakna antara variabel dependen dan variabel independen. Penelitian ini juga menggunakan nilai $O d d$ Ratio untuk menentukan risiko variabel independen terhadap variabel dependen. Nilai $\mathrm{OR}<1$ merupakan faktor protektif, nilai $\mathrm{OR}=1$ bukan merupakan faktor risiko, dan nilai $\mathrm{OR}>1$ merupakan faktor risiko. Analisis multivariat dengan regresi logistik berganda untuk mengetahui variabel yang paling bermakna dengan interval kepercayaan $95 \%$ dan tingkat kemaknaan $\mathrm{p}<0,05 .{ }^{19}$

Penelitian ini telah mendapatkan lolos kaji etik dari Komisi Etik Penelitian Fakultas Kedokteran Universitas Andalas, Padang.

\section{Hasil}

Hasil penelitian pada Tabel 1 menunjukkan bahwa responden terbanyak adalah bayi berusia 3 minggu- 6 bulan, yaitu 59 (72\%), bayi laki-laki 45 (54,9\%), bayi yang tidak memiliki riwayat keluarga PRGE 60 $(73,2 \%)$, bayi tidak BBLR $70(85,4 \%)$, tidak prematur $67(81,7 \%)$, dan bayi yang tidak memiliki riwayat konsumsi susu formula $56(68,3 \%)$ bayi.

Hasil analisis pada Tabel 2 menunjukkan bahwa bayi yang mengalami PRGE paling banyak berusia 3 minggu-6 bulan, yaitu $30(73,2 \%)$ bayi dan berjenis kelamin laki-laki, yaitu $21(51,2 \%)$ bayi.

Hasil analisis Tabel 3 menunjukkan bahwa tidak terdapat hubungan antara riwayat keluarga dengan PRGE pada bayi $(p>0,05)$. Sementara itu, terdapat hubungan yang bermakna antara berat bayi lahir, usia gestasi, dan riwayat konsumsi susu formula $(\mathrm{p}<0,05)$. Bayi yang memiliki riwayat BBLR, prematur dan konsumsi susu formula, berisiko 6,$3 ; 5,2 ; 3,2$ kali mengalami PRGE.
Hasli analisis Tabel 4 menunjukkan bahwa riwayat konsumsi susu formula merupakan faktor risiko yang paling dominan secara signifikan dengan PRGE pada bayi. Anak yang memiliki riwayat konsumsi susu formula 3,2 kali berisiko mengalami PRGE.

Tabel 1. Karakteristik sampel

\begin{tabular}{|c|c|c|}
\hline & $f$ & $\%$ \\
\hline \multicolumn{3}{|l|}{ Usia } \\
\hline 3 minggu -6 bulan & 59 & 72 \\
\hline $7-12$ bulan & 23 & $28 \%$ \\
\hline \multicolumn{3}{|l|}{ Jenis kelamin } \\
\hline Laki-laki & 45 & 54,9 \\
\hline Perempuan & 37 & 45,1 \\
\hline \multicolumn{3}{|l|}{ Riwayat keluarga } \\
\hline Ada & 22 & 26,8 \\
\hline Tidak ada & 60 & 73,2 \\
\hline \multicolumn{3}{|l|}{ Berat bayi lahir } \\
\hline BBLR & 12 & 14,6 \\
\hline Tidak BBLR & 70 & 85,4 \\
\hline \multicolumn{3}{|l|}{ Usia gestasi } \\
\hline Prematur & 15 & 18,3 \\
\hline Tidak prematur & 67 & 81,7 \\
\hline \multicolumn{3}{|c|}{ Riwayat konsumsi susu formula } \\
\hline Ada & 26 & 31,7 \\
\hline Tidak ada & 56 & 68,3 \\
\hline Jumlah & 82 & 100 \\
\hline
\end{tabular}

Ket: BBLR: berat bayi lahir rendah

Tabel 2. Distribusi frekuensi PRGE

\begin{tabular}{|c|c|c|}
\hline & \multicolumn{2}{|c|}{ PRGE } \\
\hline & PRGE & Normal \\
\hline & $\mathrm{f}(\%)$ & $\mathrm{f}(\%)$ \\
\hline \multicolumn{3}{|l|}{ Usia } \\
\hline 3 minggu - 6 bulan & $30(73,2)$ & $29(70,7)$ \\
\hline $7-12$ bulan & $11(26,8)$ & $12(29,3)$ \\
\hline \multicolumn{3}{|l|}{ Jenis kelamin } \\
\hline Laki-laki & $21(51,2)$ & $24(58,5)$ \\
\hline Perempuan & $20(48,8)$ & $17(41,5)$ \\
\hline Jumlah & 41 & 41 \\
\hline
\end{tabular}

Ket: PRGE : penyakit refluks gastroesofagus 
Puthisari Zonya Jannata dkk: Hubungan riwayat keluarga, berat bayi lahir, usia gestasi, dan riwayat konsumsi susu formula dengan PRGE pada bayi usia 3 minggu - 12 bulan

Tabel 3. Analisis bivariat

\begin{tabular}{|c|c|c|c|c|}
\hline & \multicolumn{2}{|c|}{ PRGE } & \multirow{2}{*}{$\mathrm{p}$} & \multirow{2}{*}{$\begin{array}{c}\text { OR } \\
\text { (IK95\%) }\end{array}$} \\
\hline & $\begin{array}{l}\text { PRGE } \\
\mathrm{f}(\%)\end{array}$ & $\begin{array}{c}\text { Normal } \\
\mathrm{f}(\%)\end{array}$ & & \\
\hline \multicolumn{5}{|l|}{ Riwayat keluarga } \\
\hline Ada & $13(31,7)$ & $9(22)$ & \multirow[t]{2}{*}{0,455} & 1,651 \\
\hline Tidak & $28(68,3)$ & $32(78)$ & & $(0,614-4,441)$ \\
\hline \multicolumn{5}{|l|}{ Berat bayi lahir } \\
\hline BBLR & $10(24,4)$ & $2(4,9)$ & \multirow[t]{2}{*}{0,029} & 6,290 \\
\hline Tidak BBLR & $31(75,6)$ & $39(95,1)$ & & $(1,283-30,838)$ \\
\hline \multicolumn{5}{|l|}{ Usia gestasi } \\
\hline Prematur & $12(29,3)$ & $3(7,3)$ & \multirow[t]{2}{*}{0,022} & 5,241 \\
\hline Tidak prematur & $29(70,7)$ & $38(92,7)$ & & $(1,353-20,306)$ \\
\hline \multicolumn{5}{|l|}{ Riwayat konsumsi susu formula } \\
\hline Ada & $18(43,9)$ & $8(19,5)$ & \multirow[t]{2}{*}{0,033} & 3,228 \\
\hline Tidak ada & $23(56,1)$ & $33(80,5)$ & & $(1,201-8,675)$ \\
\hline \multicolumn{5}{|c|}{ Keterangan: $\mathrm{p}<0,05=$ memiliki hubungan bermakna } \\
\hline \multicolumn{5}{|l|}{ Tabel 4. Analisis multivariat } \\
\hline Variabel & & $\mathrm{p}$ & & OR (IK95\%) \\
\hline Berat bayi lahir & & 0,152 & & $3,628(0,622-21,179)$ \\
\hline Usia gestasi & & 0,122 & & $3,297(0,727-14,946)$ \\
\hline Riwayat konsumsi susu formula & & 0,027 & & $3,219(1,139-9,097)$ \\
\hline
\end{tabular}

\section{Pembahasan}

Kami mendapatkan bayi yang mengalami PRGE lebih banyak pada usia 3 minggu - 6 bulan, yaitu $30(73,2 \%)$. Angka ini serupa dengan penelitian Yuliantari ${ }^{15}$ dengan menggunakan kuesioner yang sama, bayi PRGE ditemukan lebih tinggi pada usia $<6$ bulan $(71,4 \%)$. Selain itu, penelitian kohort oleh Curien-Chotard dan Jantchou ${ }^{3}$ juga melaporkan prevalensi PRGE pada bayi yang menurun seiring dengan bertambahnya usia, yaitu usia 1 bulan (19\%), 3 bulan (9\%), 6 bulan (5\%), 10 bulan (2\%), dan 12 bulan (2\%).

Penyakit RGE merupakan salah satu dari gangguan saluran cerna fungsional yang berkaitan dengan fungsi saluran cerna bayi yang belum sepenuhnya berkembang. ${ }^{2}$ Otot sfingter esofagus pada bayi yang masih lemah dan tidak dapat menutup sempurna akan meningkatkan terjadinya regurgitasi dikarenakan kemungkinan ASI yang diminum dapat ke luar kembali saat bayi disusui dengan posisi terlentang. ${ }^{14}$ Namun, kejadian ini menurun seiring dengan bertambahnya usia, dimulai ketika bayi berusia lebih dari 6 bulan, diduga salah satu faktor karena bayi mulai bisa duduk. ${ }^{20}$
Kami mendapatkan persentase bayi PRGE laki-laki $21(51,2 \%)$ dan perempuan $20(48,8 \%)$. Angka tersebut serupa dengan hasil penelitian Hasibuan $\mathrm{dkk}^{9}$ terhadap hasil pemeriksaan endoskopi bayi dengan gejala PRGE. Hasibuan $\mathrm{dkk}^{9}$ melaporkan 58 pasien, terdiri dari 32 laki-laki dan 26 perempuan. Namun, penelitian Kandasamy ${ }^{20}$ melaporkan sedikit berbeda, yaitu PRGE pada bayi usia 6-24 bulan ditemukan perbandingan antara laki-laki dan perempuan 3:2. Hal ini disampaikan bahwa tidak ada perbedaan pasti antara kejadian PRGE pada jenis kelamin dan semua berisiko sama. ${ }^{15}$

Kami tidak mendapatkan hubungan antara riwayat keluarga PRGE dengan kejadian PRGE pada bayi. Sejalan dengan Hegar $\mathrm{dkk}^{22}$ menggunakan kuesioner I-GERQ yang melaporkan bahwa tidak terdapat hubungan antara PRGE pada bayi usia 6-9 bulan dengan gejala PRGE pada keluarga. Namun, hasil ini bertentangan dengan Curien-Chotard yang melaporkan bahwa terdapat hubungan antara riwayat keluarga PRGE dengan kejadian PRGE pada bayi. ${ }^{3}$ Selain itu, Martin ${ }^{23}$ juga melaporkan bahwa terdapat hubungan antara ibu yang mengalami PRGE dengan gejala regurgitasi pada bayi. Namun, penelitian ini tidak 
Puthisari Zonya Jannata dkk: Hubungan riwayat keluarga, berat bayi lahir, usia gestasi, dan riwayat konsumsi susu formula dengan PRGE pada bayi usia 3 minggu - 12 bulan

memperlihatkan hubungan antara gejala PRGE pada ayah dengan regurgitasi pada bayi.

Riwayat keluarga dengan PRGE pada generasi pertama atau generasi kedua diduga merupakan faktor risiko yang kuat untuk PRGE pada bayi yang dikaitkan dengan adanya peran genetik. ${ }^{3}$ Nelson $^{24}$ dan Filges ${ }^{25}$ menyebutkan bahwa lokasi kromosom yang diduga terlibat adalah kromosom 13q14 yang lokusnya dinamakan GERD1. Lokus tersebut terdapat gen HTR2A, yaitu sebuah kode untuk reseptor 2-hydroxytriptamine $2 \mathrm{~A}$ yang berkaitan dengan peran serotonin yang memengaruhi fungsi otot polos dan miogenesis diseluruh saluran pencernaan. ${ }^{24-26}$ Gejala spesifik untuk PRGE pada dewasa adalah rasa terbakar didada dan/atau regurgitasi yang muncul setelah makan. Namun, gejala tersebut bukan penanda pasti untuk PRGE. Kuesioner GERD (GERD-Q) hanya salah satu alat untuk membantu diagnosis PRGE (sensitivitas dan spesifisitas sebesar $65 \%$ dan $71 \%$ ). ${ }^{27}$ Selain itu, pada penelitian ini riwayat kedua orang tua dengan PRGE hanya ditanyakan melalui ibu saja, tidak ditanyakan langsung ke kedua orang tua.

Kami mendapatkan hubungan berat bayi lahir dengan kejadian PRGE pada bayi. Penelitian Yuliantari ${ }^{15}$ melaporkan hasil serupa, yaitu terdapat hubungan antara BBLR dengan kejadian RGE. Dahlen $\mathrm{dkk}^{13}$ juga melaporkan bahwa BBLR merupakan faktor risiko yang cukup tinggi untuk PRGE, yaitu sekitar 30-50\%. Namun, hasil ini tidak sejalan dengan $\mathrm{Silmi}^{28}$ yang melaporkan bahwa tidak terdapat hubungan antara BBLR dengan regurgitasi.

Berbagai masalah sistem pencernaan dapat ditemukan pada bayi dengan BBLR, seperti lambung yang kecil, enzim pencernaan yang belum matang, dan alat pencernaan seperti sfingter esofagus bawah (SEB) yang imatur sehingga dapat mengakibatkan peluang kejadian RGE lebih meningkat. ${ }^{159}$ Gangguan pernapasan yang sering dijumpai pada BBLR juga diduga menyebabkan regurgitasi karena ketika bayi bernafas abnormal (lebih cepat dan lebih keras), otot di bagian atas lambung akan meregangkan sfingter esofagus dan menyebabkan relaksasi yang menetap secara kronik sehingga regurgitasi akan terjadi. ${ }^{15}$

Kami mendapatkan hubungan antara usia gestasi dengan kejadian PRGE. Serupa dengan penelitian Dahlen $\mathrm{dkk}^{13}$ bahwa terdapat hubungan yang kuat antara bayi prematur dengan kejadian PRGE. Forssell $\mathrm{dkk}^{30}$ juga melaporkan risiko esofagitis meningkat pada individu yang lahir dengan prematur. Namun, penelitian ini tidak sejalan dengan penelitian Steutel $\mathrm{dkk}^{30}$ yang melaporkan tidak terdapat hubungan antara usia gestasi dengan kejadian PRGE. 5

Terjadinya RGE pada bayi prematur disebabkan oleh berbagai faktor terkait imaturitas organ dan sistem pencernaan. ${ }^{31}$ Perkembangan esofagus dimulai sejak usia gestasi 20 minggu dan lambung mulai dari 28 minggu. Refleks menghisap juga saat minggu ke-28 dan refleks menelan saat minggu ke 33-36. ${ }^{32}$ Respon motorik esofageal terhadap stimulasi intraluminal oleh isi lambung mulai jelas setelah usia gestasi 33 minggu. ${ }^{31}$ Episode Transient lower esophageal sphimcter relaxation (TLESR) dapat terjadi puluhan kali setiap harinya pada bayi prematur sehingga meningkatkan regurgitasi. Pengosongan lambung yang lambat, tonus LES yang lemah $(<5 \mathrm{mmHg})$, kapasitas lambung yang kecil, esofagus yang lebih pendek dan sempit, serta gerakan peristaltik yang belum sempurna juga berkontribusi terhadap rendahnya klirens refluks dari esofagus yang akan menyebabkan regurgitasi pada bayi. ${ }^{33,31}$

Hasil penelitian kami mendapatkan hubungan antara riwayat konsumsi susu formula dengan kejadian PRGE pada bayi dan riwayat konsumsi susu formula menjadi faktor yang paling dominan memengaruhi kejadian PRGE pada bayi. Bayi yang mengonsumsi susu formula berisiko 3,2 kali mengalami PRGE. Penelitian ini sejalan dengan Serinurani ${ }^{34}$ yang melaporkan hasil bahwa terdapat hubungan antara pemberian susu formula dengan RGE. Bayi yang mengonsumsi susu formula mempunyai tingkat frekuensi regurgitasi yang lebih tinggi dibandingkan bayi yang mengonsumsi ASI eksklusif. ${ }^{35}$ Namun, Curien-Chotard dan Jantchou ${ }^{3}$ tidak menemukan hubungan antara konsumsi ASI dengan PRGE dan ASI bukan merupakan faktor protektif terhadap PRGE pada bayi.

Susu formula mengandung asam lemak jenuh yang sulit dicerna menjadi nutrien yang diserap oleh tubuh sehingga mengakibatkan pengosongan lambung menjadi lebih lama yang mengakibatkan terjadinya refluks asam dan regurgitasi pada bayi. ${ }^{35}$ Bayi yang diberikan susu formula juga kemungkinan dapat mengalami cow's milk protein allergy (CMPA) atau alergi protein susu sapi. Proses infiltrasi mukosa dan aktivasi dari berbagai jenis sel inflamasi seperti sel mast yang dianggap sebagai sel efektor utama dari reaksi hipersensitivitas akan melepaskan sejumlah neurotransmiter diseluruh saluran gastrointestinal. Sel mast tersebut di dalam saluran cerna berada di dekat ujung saraf sehingga dapat terjadi respon neuromuskular, seperti kontraksi otot dan refleks saraf 
Puthisari Zonya Jannata dkk: Hubungan riwayat keluarga, berat bayi lahir, usia gestasi, dan riwayat konsumsi susu formula dengan PRGE pada bayi usia 3 minggu - 12 bulan

yang dapat mengakibatkan perubahan fungsi motorik gastrointestinal sehingga meningkatkan regurgitasi pada bayi. ${ }^{37}$

\section{Kesimpulan}

Bayi yang mengalami PRGE paling banyak terjadi pada usia 3 minggu - 6 bulan dan berjenis kelamin laki-laki. Terdapat hubungan antara berat bayi lahir, usia gestasi, dan riwayat konsumsi susu formula dengan kejadian PRGE pada bayi, Riwayat konsumsi susu formula merupakan faktor risiko yang paling berpengaruh terhadap PRGE pada bayi usia 3 minggu - 12 bulan di Puskesmas Andalas, Padang.

\section{Daftar pustaka}

1. Poddar U. Gastroesophageal reflux disease (GERD) in children. Paediatr Child Heal (United Kingdom) 2018;39:7-12.

2. Subijanto, Firmansyah A, Juffrie M, dkk. Rekomendasi Gangguan Saluran Cerna Fungsional. Edisi ke-1. Ranuh RG, Athiyyah AF, Syarif BH, penyunting. Jakarta: Badan Penerbit Ikatan Dokter Anak Indonesia; 2016.

3. Curien-Chotard M, Jantchou P. Natural history of gastroesophageal reflux in infancy: New data from a prospective cohort. BMC Pediatr 2020;20:1-8.

4. Hegar B, Dewanti NR, Kadim M, Alatas S, Firmansyah A, Vandenplas Y. Natural evolution of regurgitation in healthy infants. Acta Paediatr Int J Paediatr 2009;98:1189-93.

5. Steutel NF, Zeevenhooven J, Scarpato E, dkk. Prevalence of Functional gastrointestinal disorders in European infants and toddlers. J Pediatr 2020;221:107-14.

6. Esposito C, Roberti A, Escolino M, dkk. Management of gastroesophageal reflux disease in pediatric patients: a literature review. Pediatr Heal Med Ther 2015;6:1-8.

7. Baird DC, Harker DJ, Karmes AS. Diagnosis and treatment of gastroesophageal reflux in infants and children. Am Fam Physician 2015;92:705-14.

8. Rala S, Çakir M, Köse T, Bor S, Aydoğdu S. Prevalence of gastroeusophageal reflux disease and reflux-related symptoms in infants; development and validation of a novel gastroesophageal reflux disease questionnaire to use for Turkish Infants (SM Reflux Questionnaire) 2014;1:190.

9. Hasibuan B, Hegar B, Kadim M. Derajat kerusakan mukosa esofagus pada anak dengan penyakit refluks gastroesofagus. Sari Pediatri 2016;14:19.

10. Andini AD. Hubungan penyakit refluks gastroesofagus dengan status gizi bayi usia 1 sampai 12 bulan di posyandu wilayah kerja Puskesmas Seberang Padang. J Ilmu Kesehat Indones. 2020;21:1-9.
11. Maheen H, Woodey FW, Mousa H. Esophageal clearance in gastroesophageal reflux. Dalam: Vandenplas Y, penyunting. Gastroesophageal Reflux in Children. Brussels: Springer; 2017.h.41.

12. Khan S. Complications of gastroesophageal reflux disease. Dalam: Kliegman RM, ST Geme JW, penyunting. Nelson Textbook of Pediatrics. Edisi ke-21. Philadelphia, PA: Elsevier; 2020.h.7694-5.

13. Dahlen HG, Foster JP, Psaila K, dkk. Gastro-oesophageal reflux: A mixed methods study of infants admitted to hospital in the first 12months following birth in NSW (2000-2011). BMC Pediatr 2018;18:1-15.

14. Hutabarat J. Teknik menyusui berhubungan dengan kejadian regurgitasi pada bayi 0-3 bulan. Maj Ilm Methoda 2018;8:55-60.

15. Yuliantari KR, Manoppo JIC, Lestari H. Hubungan antara bayi berat lahir rendah dengan kejadian refluks gastroesofagus di puskesmas Kecamatan Malalayang. e-CliniC 2016;4:1-7.

16. Kementrian Kesehatan RI. Profil Kesehatan Indonesia Tahun 2019. Jakarta: Kemkes RI; 2020.

17. Dinas Kesehatan Kota Padang. Profil Kesehatan Kota Padang Tahun 2019. Padang: Dinkes Kota Padang; 2020.

18. Dinas Kesehatan Kota Padang. Profil Kesehatan Kota Padang Tahun 2018. Dinas Kesehatan Kota Padang. Padang: Dinkes Kota Padang 2019.

19. Sastroasmono S. Dasar-dasar metodologi penelitian klinis. Edisi ke-4. Jakarta: Sagung Seto; 2011.

20. Kandasamy E, Andy SK. A cross-sectional study on prevalence of gastro esophageal reflux disease in regurgitant infant and children with evaluation of IGERQ score. Int J Contemp Pediatr 2018;5:396.

21. Duncan DR, Rosen RL. Current insights into the pharmacologic and nonpharmacologic management of gastroesophageal reflux in infants. Neoreviews 2016;17:e203-12.

22. Hegar B, Satari DHI, Sjarif DR, Vandenplas Y. Regurgitation and gastroesophageal reflux disease in six to nine months old Indonesian infants. Pediatr Gastroenterol Hepatol Nutr 2013;16:240-7.

23. Martin AJ, Pratt N, Kennedy JD, dkk. Natural history and familial relationships of infant spilling to 9 years of age. Pediatrics 2002;109:1061-7.

24. Khan S. Gastroesophageal reflux disease. Dalam: Kliegman, penyunting. Nelson Textbook of Pediatrics. Edisi ke-21. Philadelphia, PA: Elsevier; 2020.h.7683-4.

25. Filges I, Furlano RI. The genetics of GER and GERD. Dalam: Till H, Thomson M, Foker JE, Holcomb GW, Khan KM, penyunting. Esophageal and gastric disorders in infancy and childhood. Berlin: Springer; 2017.h.835-42.

26. Orenstein SR, Shalaby TM, Barmada M, Whitcomb DC. Genetics of gastroesophageal reflux disease: A review. J Pediatr Gastroenterol Nutr 2002;34:506-10.

27. Makmun D, Abdullah M, Fahrial Syam A, dkk. Revisi Konsensus Nasional Penatalaksanaan Penyakit Refluks Gastroesofageal (Gastroesophageal Reflux Disease/GERD) di Indonesia. Edisi ke-2. Fahrial Syam A, Aulia C, Renaldi $\mathrm{K}$, penyunting. Jakarta: Pengurus Besar Perkumpulan Gastroenterologi Indonesia; 2013. 
Puthisari Zonya Jannata dkk: Hubungan riwayat keluarga, berat bayi lahir, usia gestasi, dan riwayat konsumsi susu formula dengan PRGE pada bayi usia 3 minggu - 12 bulan

28. Silmi BT. Faktor risiko regurgitasi pada bayi usia 0-6 bulan studi analitik observatif di Desa Penggaron Lor Semarang, tesis. Semarang: Fakultas Kedokteran UNISSULA, 2014.

29. Ernawati A. Gambaran kejadian berat badan lahir rendah di Kabupaten Pati. J litbang 2015;XI:46-55.

30. Forssell L, Cnattingius S, Bottai M, Lagergren J, Ekbom A, Akre O. Risk of esophagitis among individuals born preterm or small for gestational age. Clin Gastroenterol Hepatol 2012;10:1369-75.

31. Marsubrin PMT, Mulyana K, Roeslami RD. Review: refluks gastroesofageal pada bayi prematur. Maj Kedokt UKI. 2019;XXXV:128-36.

32. Nasar SS. Tata laksana nutrisi pada bayi berat lahir rendah.
Sari Pediatri 2004;5:165-70.

33. Eichenwald EC, Yogman M, Lavin CA, dkk. Diagnosis and management of gastroesophageal reflux in preterm infants. Pediatrics 2018;142:1-5.

34. Serinurani I, Ardie F, Prasodjo. Perbedaan frekuensi regurgitasi pada bayi usia 0-6 bulan aterm yang diberi ASI eksklusif dan susu formula di wilayah kerja Puskesmas Balongsari Kotamadya Mojokerto. Saintika Med J Ilmu Kesehat dan Kedokt Kel 2012;8:103-8.

35 Valitutti F, Rybak A, Borrelli O. Gastro-oesophageal reflux and cow's milk allergy. Dalam: Vandenplas Y, penyunting. Gastroesophageal Reflux in Children. Brussels: Springer; 2017. h.203-5. 